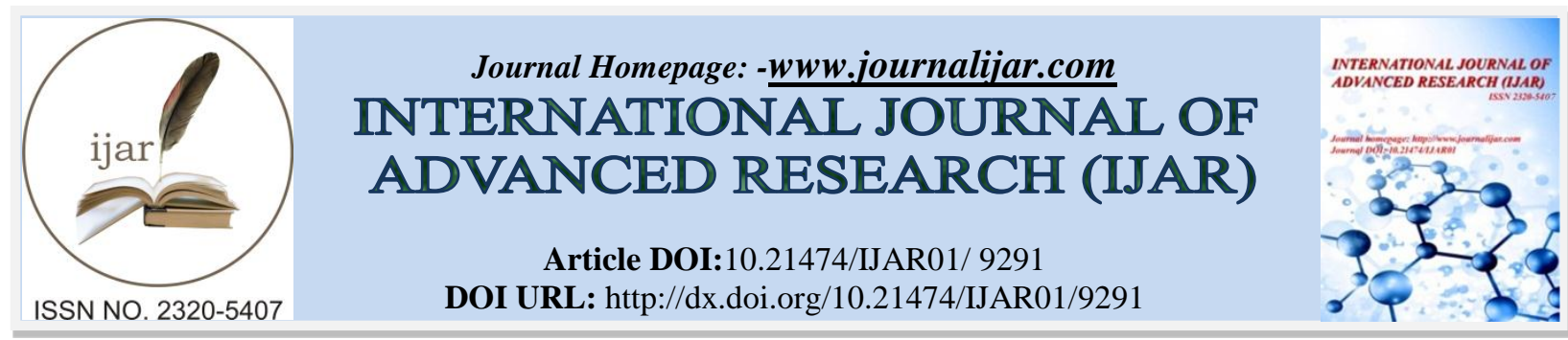

RESEARCH ARTICLE

\title{
AYURVEDIC APPROACH OF GARBHINI PARICHARYA (REGIMEN FOR PREGNANT WOMEN).
}

\section{Dr. Ajinkya Gite ${ }^{1}$,Dr. Krishna Rathod ${ }^{2}$ and Dr. Hemant Toshikhane ${ }^{3}$.}

1. PG Scholar Dept. of Shalyatantra, Parul Institute of Ayurved, Parul University, Vadodara, Gujarat,India.

2. Assistant Professor and PhD. Scholar Ayurved Samhita \& Siddhant, Parul Institute of Ayurved Parul University, Vadodara, Gujarat, India.

3. Dean and Principal: MS( Shalyatantra ) PhD,MBA; Faculty of Ayurved, Parul University, Vadodara, Gujarat,India.

\section{Manuscript Info}

\section{Manuscript History}

Received: 15 April 2019

Final Accepted: 17 May 2019

Published: June 2019

Key words:-

Garbhini Paricharya, Ayurveda,

Pregnancy, Regime.

\section{Abstract}

Garbhini individual where in garbha dwells or halts of garbha is termed as garbhini.paricharya the word "paricharya" is derived from the root "chara-gatau" with prefix "pari". charya that means to service or nuthe garbhini paricharya is the care given to pregnant woman in necessary all respectful manner it's very important for future social impact assessment. The month wise paricharya described in the Ayurveda that helps proper (samyaka) healthy growth and development of foetus and gives health and care to mother. Our Ayurved acharyas know very well that not only the food and environment play a vital role in the development of foetus but also maternal psychic impressions have their impact on a growing foetus.

Copy Right, IJAR, 2019,. All rights reserved.

\section{Introduction:-}

The skin and nails become smooth and Garbhini attains high degree of Bala, Varna and Ojas. She also reposes timely the mother's body parts like abdomen, flanks, back and genital organs become Mridu and Vatanulomana occurs. The natural urges (vega) are expelled out easily, through their respective Srotasa (openings).All these factors contribute in the full development and delivery of a child with all qualities and health.Contrary to this, if a Garbhini does not follow the above necessary Paricharya, that may result in many problems regarding health of both mother and fetus and also result in such complications which may need immediate attention.

Classical Garbhini Paricharya with their Benefits of Garbhini Paricharya:

Masanumasik Garbhini Paricharya

\begin{tabular}{|l|l|l|l|}
\hline Month & Charak Samhita & Sushruta Samhita & Vagbhata \\
\hline $1^{\text {st }}$ Month & $\begin{array}{l}\text { Kshera (Non- } \\
\text { Medicated ) }\end{array}$ & Sita,Madhura,Drava aahar & $\begin{array}{l}\text { Ksheera (Medicated } \\
\text { Sarpi Extraced from } \\
\text { Ksheer with Salparni \& } \\
\text { Palasa, water boiled with } \\
\text { Kanak \& Rajat then } \\
\text { cooled and taken }\end{array}$ \\
\hline $2^{\text {nd }}$ Month & $\begin{array}{l}\text { Ksheera with } \\
\text { Madhura Dravya }\end{array}$ & Sita Madhur dravya aahar & $\begin{array}{l}\text { Ksheera with Madhura } \\
\text { Dravya }\end{array}$ \\
\hline
\end{tabular}

Corresponding Author:-Dr. Ajinkya Gite.

Address:- PG Scholar Dept. of Shalyatantra, Parul Institute of Ayurved, Parul University, Vadodara, 


\begin{tabular}{|c|c|c|c|}
\hline $3^{\text {rd }}$ Month & $\begin{array}{l}\text { Ksheer with madhu } \\
\& \text { sarpi }\end{array}$ & $\begin{array}{l}\text { Sita Madhur drava aahar specialy Made Sastik } \\
\text { Dhanya with Ksheera }\end{array}$ & $\begin{array}{l}\text { Ksheera with madhu and } \\
\text { sarpi }\end{array}$ \\
\hline $4^{\text {th }}$ Month & $\begin{array}{l}\text { Navneet with Ksheer } \\
\text { or Navneet extracted } \\
\text { from Ksheera }\end{array}$ & $\begin{array}{l}\text { Sastik with dadhi, jangle mamsa along with } \\
\text { ksheer and navanita }\end{array}$ & Ksheera with sarpi \\
\hline $5^{\text {th }}$ Month & Ksheer with sarpi & $\begin{array}{l}\text { Sastik with dadhi, jangle mamsa along with } \\
\text { ksheer and navanita }\end{array}$ & Ksheera with sarpi \\
\hline $6^{\text {th }}$ Month & $\begin{array}{l}\text { Sarpi prepared from } \\
\text { ksheer with madhura } \\
\text { dravya }\end{array}$ & Sarpi or yavagu medicated with gokshura & $\begin{array}{lcr}\text { Sarpi } & \text { prepared from } \\
\text { ksheer } & \text { with madhura } \\
\text { dravya } & & \end{array}$ \\
\hline $7^{\text {th }}$ Month & $\begin{array}{l}\text { Sarpi prepared from } \\
\text { ksheer with madhura } \\
\text { dravya }\end{array}$ & Sarpi medicated with vidangadi gana & $\begin{array}{lcr}\text { Sarpi } & \text { prepared } & \text { from } \\
\text { ksheer } & \text { with } & \text { madhura } \\
\text { dravya } & & \end{array}$ \\
\hline $8^{\text {th }}$ Month & $\begin{array}{l}\text { Yavagu prepared } \\
\text { with ksheer mixed } \\
\text { with ghrita }\end{array}$ & $\begin{array}{l}\text { Asthapan basti with patal,mastu and sata- } \\
\text { puspa,bala,dadhi,lavan,madhu,madanphala } \\
\text { followed by ahvasan vasti with oilsand madhura } \\
\text { varga after that treated with snigdha yavagu } \\
\text { jangal mamsa }\end{array}$ & $\begin{array}{l}\text { Yavagu prepared with } \\
\text { ksheer and mixed with } \\
\text { ghrita with oil,madhura } \\
\text { varga after that treated } \\
\text { with snigdha yavagu \& } \\
\text { jangal mamsa }\end{array}$ \\
\hline $9^{\text {th }}$ Month & $\begin{array}{l}\text { Anuvasan basti with } \\
\text { oil and madhur varga }\end{array}$ & & $\begin{array}{l}\text { Anuvasan basti with oil } \\
\text { and Madhur varga }\end{array}$ \\
\hline
\end{tabular}

\section{Benefits Of Garbhini Paricharya(2)}

They can be categorized under following headings:

1. Moodha Garbha

2. Garbha Vyapat

3. Dushprajataja Amayas.

\section{Moodha Garbha :}

Sushruta, in his "Moodha Garbha Nidana" has mentioned the aetiological factors of Moodha Garbha as Adhvagamana, Praskhalana, etc. These factors are nothing but the contra indicated Ahara-Viharas in duration gestational life.

\section{Garbha Vyapat :}

Charaka, while describing the Garbha Upaghatakara Bhavas mentioned that if a woman follows the Apatya Viharas like Utkatasan, Vishamasan Kathinasan etc., she is more prone to have Garbha Vyapats like early abortiions, midtrimester abortions, IUGR, IUD etc. He also states that if Garbhini takes Apathya Ahara, it will lead to Upavishtaka, Nagodara etc. diseases in Garbha.

\section{Dushprajataja Amayas :}

Sushruta, described in the 8th month Garbhini Paricharya, stated that the Basti chikitsa which is given in this month helps in Prakrita Prasava. In Kashyapa Samhita, it has been stated that Asamyak Garbhini Paricharya which is results into Aprakrita Prasava which leads into 64 Dushprajataja Amayas. So, these all clearly indicate that for the best growth \& development of foetus and for Prakrits Prasava, following of Garbhini Paricharya is very much essential.

\section{General remedies that should (compulsary) be followed and imprortant to avoid by garbhini :}

They have given equal importance to all factors. The do"s and don'ts which influence these factors are shown in the table.

To follow and avoid in gestation period.

Follow

1. Take congenial diet.
Avoid

1. Avoid Tikshna, Ushna, GuruAhara and Aushadhas. 


\begin{tabular}{|l|l|}
\hline $\begin{array}{l}\text { 2. Use Hridya, Drava, Madhura, } \\
\text { Snigdha substances treated with } \\
\text { Deepana Dravyas. }\end{array}$ & $\begin{array}{l}\text { 2. Avoid Madakaraka Dravyas like } \\
\text { wine etc. }\end{array}$ \\
\hline $\begin{array}{l}\text { 3. Use Jeevaniya group of drugs } \\
\text { both externally and internally. }\end{array}$ & 3. Not to take meat excessively. \\
\hline 4. Use butter, ghee and milk. & $\begin{array}{l}\text { 4. Give up Atitarpana and } \\
\text { Atikarshana Ahara. }\end{array}$ \\
\hline $\begin{array}{l}\text { 5. Take the diet according to living } \\
\text { place, season and agni. }\end{array}$ & $\begin{array}{l}\text { 5. Avoid dried, wet, putrified, stale } \\
\text { food. }\end{array}$ \\
\hline 6. Use hot water. & 6. Avoid Vishtambi Ahara. \\
\hline $\begin{array}{l}\text { 7. Take Surana and Vibandhakara } \\
\text { substances along with juices. }\end{array}$ & $\begin{array}{l}\text { 7. Not to take Dwidala Ahara, } \\
\text { Vidahi, Guri Amla substances } \\
\text { and Ushna Dugdha. }\end{array}$ \\
\hline & 8. Not to eat clay, Surana etc. \\
\hline
\end{tabular}

To Follow :-

1. Maintain good conduct.

2. Sleeping and sitting places (a) covered with soft cushion or mattress.

3. During Grahana, go into Garbhagriha and offer oblation to free from the clutches of Grahas

4. Offer alms to beggars.

Avoid :-

1. Not to do excessive Vyayama and Vyavaya.

2. Not to ride over vehicles.

3. contain pillow.

4. perfect and very comfortable.

5. Give up the things contrary to Indriyas and other harmful articles.

6. Avoid Divaswapna and Ratrijagarana

7. Avoid Utkatasana etc.

8. Avoid Akala Poorvakarma, Panchakarma, Raktamokshana.

9. Avoid Vega Vidharana.

10. Avoid outing, visiting of lonely places, cremation ground, Chaityas etc.

11. Avoid high pitch talk.

12. Not to be fatigued.

13. Avoid articles likely to aggravate Doshas.

14. Avoid Peeping in the pit or well.

15. Avoid sleeping in supine position.

16. Not to look at descending noon, setting sun and both the Rahus.

\section{Hygiene For Garbhini}

\section{Follow:}

1. Wear clean, white and loose garments

2. Wear ornaments.

3. Living place should be free from insects like mosquitoes etc.

4. Take bath daily.

Avoid:

1. Not to wear red garments.

2. Not to touch dirty or disfigured persons possessing less body parts

3. Give up foul smelling, awful looking substances.

\section{Conduct for garbhini (psychological health)Follow:}

1. Be happy.

2. Live a pious life.

3. Perform joyful functions.

4. Perform auspicious deeds. 
5. Worship Diety, Brahmanas \& priest.

6. Husband and relatives should behave affectionately.

7. Should follow Apta Vachana.

Avoid:

1. Avoid utter harsh words and violent activities.

2. Avoid grief, fear etc.

3. Give up exciting stories.

4. Avoid the places where thoughts likely to promote anger, fear etc.

Monthly regimen for a pregnant woman:

Along with these generalized GUIDELINES, Acharyas have described the specific month wise management of a pregnant woman to Compensate the requirements of mother as well as growing foetus. These are as follows :

Masanumasika Garbhini Paricharya

Month wise regimen mentioned in Ayurved Samhitas in Month

1. Non medicated milk

2. Favourable Ahara twice daily.

3. Madhura, Sheeta, Drava Ahara.

4. Milk medicated with Garbha Sthapana Dravyas for twice a day.

5. First 12 days - Ksheerodhrita Ghrita medicated with Shalaparni and Palasa.

6. Drink water, boiled with gold or silver and cooled.

7. Yashti, Parushaka, Madhuka alone or combined with butter and honey followed by

8. Madhura Ksheera.

\section{Month}

1. Milk medicated with Madhura group.

2. Madhura, Sheeta, Drava Ahara.

3. Madhura Ksheera treated with Kakoli.

\section{Month}

1. Milk with honey and ghee.

2. Madhura, Sheeta, Drava Ahara.

3. Cooked Shashti rice with milk.

4. Krisara.

\section{Month}

1. Butter prepared from milk (or) Milk with butter in Aksha (2 tolas) Matra

2. Cooked Shashti rice with Dadhi and Hridya Ahara with adequate quantity of Ksheera

3. Navaneetam and Jangala Mamsa.

4. Prativihita Ksheera with milk.

5. Kritaudanam.

\section{Month}

1. Ghrita extracted from milk or Ghrita with milk.

2. Shashti rice with milk and Hridya Ahara with adequate quantity of Ksheera Sarpi.

3. Ksheera Sarpi alone (ghee extracted from milk).

4. Yavagu.

5. Payasa.

\section{Month}

1. Madhuraushadha siddha Ksheera Sarpi.

2. Ghee or Yavagu medicated with Gokshura.

3. Ksheera Sarpi alone.

4. Madhura Dadhi. 


\section{Month}

1. Madhuraushadha siddha Ksheera Sarpi.

2. Treat the Kikkisa.

3. Ghrita medicated with Prithakparnyadi group of drugs.

4. Ghrita Khanda

\section{Month}

1. Yavagu prepared with milk and mixed with Ghrita.

2. Asthapana Vasti with Badarodaka, Bala, Atibala etc. drugs and Anuvasana Vasti with Dugdha and Madhura Kashaya siddha Taila.

3. Snigdha Yavagu and Jangala Mamsarasa.

4. Ksheera Peya along with Ghrita.

5. Anuvasana Vasti with drugs of Madhura group (Draksha etc.).

6. Ghrita Puraka.

\section{Month}

1. Anuvasana Vasti with Madhuraushadha siddha Taila. b. Yoni Pichu of the same oil.

2. Snigdha Mamsarasa with Ahara of Bahu Snehayukta Yavagu.

3. Bath with Sheeta Kashaya of Vataghna drugs.

4. Various Anna.

5. Anuvasana Vasti with Kadamba oil.

6. Yavagu.

\section{Conclusion:-}

By the above details, it is clear that milk and drugs of Madhura group have been advised for entire pregnancy period. Milk is a wholesome diet. It provides nutrition and stability to the foetus. The drugs of Madhura group are having anabolic property. Hence, the use of these drugs will help in maintenance of proper health of Garbhini and development of foetus. So, the a The Garbhini who follows the such said Upakramas creates Snigdha guna garbhini Avastha , that Snigdha guna predominantly of Kapha Dosha and Kppha Dosha plays important role in nourishment which gains strength and delivers normally and easily without any complication.

\section{References:}

1. Aacharya Yadhavji Trikamji, Charak Samhita (978-81-7637-133-9) of Agnivesa, Chakrapani Datta's Ayurveda deepika (sans), Reprint edition 2015 Sharirasthan, Srotasam vimana 5/3, Chaukhambha Sanskrit Series office,Varanasi, 2015, pp 346.

2. Dr Hari Sadashiv Shastri Paradkar ,Astang Hridyam, $\left(978,93,80326-76-043^{\text {rd }}\right.$ ed 2014, Varanasi: Chaukhamba Subharati Pratisthan, (Vol I); pp377.

3. Dr. Bhaskar Govind Ghanekar,Sushruta Samhita, Sharirasthan, Reprint ed 2013, Meharchand Lachimdas Publication, New Delhi (Vol 3); pp 246

4. Dr. Ambika Datta Shatri, Sushruta Samhita, Reprint $5^{\text {th }}$ edition 2007, Varanasi:

5. Chaukhamba Sanskrit santhan, (Vol I); pp240.

6. Srikanth Murthi S.R, Astang Sangaraha, $9^{\text {th }}$ edition 2005, Varanasi: Chaukhamba Orientalia, (Vol I); pp 342.

7. Srikanth Murthi K.R., Sushruta Samhita, $1^{\text {st }}$ edition 2000, Varanasi: Chaukhamba Orientalia, (Vol I); pp346. 